\title{
Mango Malformation: I. Toxin Production Associated with Fusarium Pathogens
}

\author{
Wafaa Haggag M. ${ }^{1}$, Hazza M. ${ }^{2}$, Sehab A. ${ }^{1}$, Abd El-Wahab M. ${ }^{1}$ \\ ${ }^{1}$ Department of Plant Pathology National Research Center, Dokki, Cairo, Egypt; ${ }^{2}$ Science Faculty, Botany Department, Banha Uni- \\ versity, Banha, Egypt. \\ Email: wafaa_haggag@yahoo.com
}

Received April $2^{\text {nd }}, 2011$; revised May $4^{\text {th }}, 2011$; accepted May $18^{\text {th }}, 2011$.

\begin{abstract}
Eight Fusarium species i.e. F. subglutinans, F. solani, F. oxyspoum, F. sterilihyphosum, F. proliferatum, F. moniliforme, $F$. avena and $F$. chlamydspore isolated from mango malformed disease were tested for their ability to cause mango malformation disease and their production of moniliformin and total fumonisins (FB1 +FB2) using HPLC. A evaluated for moniliformin production, seven isolates were toxin producers, the production levels ranging from 0.51 to $8.90 \mu \mathrm{g} / \mathrm{ml}$. The higher levels were produced by Fusarium subglutinans $(8.51 \mu \mathrm{g} / \mathrm{ml})$. Moderate concentrations of moniliformin was produced by F.moniliforme $(6.90 \mu \mathrm{g} / \mathrm{ml}), \mathrm{F}$. oxysporum $(6.30 \mu \mathrm{g} / \mathrm{ml}), \mathrm{F}$. proliferatum $(4.10 \mu \mathrm{g} / \mathrm{ml})$ and F. sterilihyphosum $(1.10 \mu \mathrm{g} / \mathrm{ml})$. Separation and identification of Fumonisin that was isolated from the pathogencausing disease are made by (HPLC). A evaluated for total fumonisin production $(F B 1+F B 2)$, seven isolates were toxin producers, the production levels ranging from 0.10 to $8.30 \mu \mathrm{g} / \mathrm{ml}$. The higher levels were produced by $F$. moniliforme $(8.30 \mu \mathrm{g} / \mathrm{ml}$. Moderate concentrations of fumonisin was produced by $F$.proliferatum $(0.64 \mu \mathrm{g} / \mathrm{ml}) \mathrm{and} \mathrm{F}$. subglutinans $(0.50 \mu \mathrm{g} / \mathrm{ml})$. Strong positive correlations between moniliformin and total fumonisins $(F B 1+F B 2)$ activities and malformation disease incidence by $F$. subglutinans, F. solani, F. oxyspoum, F. sterilihyphosum, F. proliferatum was observed.
\end{abstract}

Keywords: Fusarium, Mango Malformation, Moniliformin and Fumonisins

\section{Introduction}

Mango (Mangifera indica L.) is the most important fruit grown in tropical and subtropical region of the world. Mango (Mangifera indica L.) is the most important fruit crop in Egypt. Mango Malformation is one of the most destructive mango diseases $[1,2]$. Losses due to malformation have not been accurately assessed because yield loss is not a linear function of disease severity [3]. During a survey of mango plantations in Sindh for investigating the association of fungi with mango malformation disease (MMD), six fungal species viz., Fusarium nivale (Fr.) Ces, F. oxysporium, F. moniliforme, F. semitectum, Alternari alternata and Aspergillus niger were isolated and identified on the basis of their colony characteristics and conidial morphology [4]. F. sterilihyphosum and F. proliferatum are first report association with mango malformation in [5]. As noted by [6] mango malformation probably involves two principles;1) the malformation inducing principle (MIP) which works through imbalance in growth substance and in conditioning of cells; 2)The toxic principle (TP) which causes growth retardation and toxicity symptoms. Fuarium species, particularly $F$. moniliforme var subglutinans, are likely source of MIP and TP, and the causal agent of disease. Singh and Dhillon [7] proposed that ethylene might play role in mango malformation by suppression of apical dominance, causing more isodiametric growth of rachides and shortening and thickening of secondary branches of malformed panicles. Ram [8] stated that the most probable role of malformin in the causation of mango malformation might be mediated through alteration of membrane permeability leading to efflux of IAA or its metabolite. He indicates the possibility that malformin antagonizes IAA action through efflux action of auxins of the malformed cells causing loss of apical dominance at a very early stage of panicle development. Malformed mango panicles have been shown to contain reduced levels of auxin $[7,9,10]$. Strains of Fusarium proliferatum, $F$. subglutinans, $F$. anthophilum, $F$. annulatum, F. succisae, $F$. beomiforme, $F$. dlamini, $F$. napiforme, and $F$. nygamai from a variety of substrates and geographic areas were 
tested for the production of fumonisin B1 in culture. None of the cultures of $F$. subglutinans, $F$. annulatum, $F$. succisae, or $F$. beomiforme produced fumonisin $\mathrm{B} 1$ in culture. Strains of $F$. proliferatum produced fumonisin $\mathrm{B} 1$ in amounts ranging from 155 to $2936 \mathrm{ppm}$, of the species tested, $F$. proliferatum is the most important producer of fumonisin B1 because of its association with corn and animal mycotoxicose such as porcine pulmonary edema. $F$. napiforme and $F$. nygamai also may be important because of their association with the food grains millet and sorghum [11].

Thus, objective of the present study is to study the production of toxins by pathogens involved in the causation of malformation.

\section{Materials and Methods}

Fusarium species isolated from mango malformed disease were tested for their ability to cause malformation. Mango seedlings cv. Sedekia (two years old) was inoculated with culture filtrate of Fusarium spp. by injection of the apical buds. Sterilized water was used as a control. Transplanted seedlings were monitored for development of malformation. At the end of the experiment (120 days), all surviving seedlings were examined for apical disease symptoms. Data were recorded on symptoms manifestation as diseases incidence and severity (from 1 - 4 scale).

\subsection{Determination of Moniliformin and Fumonisin}

Cultures were initially grown on agar slants for 7 - 10 days. A slant was macerated in $27 \mathrm{ml}$ of sterile water. Aliquots of $(2.5 \mathrm{ml})$ of the resulting suspension were added to $250 \mathrm{ml}$ Erlenmeyer flasks containing $50 \mathrm{ml}$ of inoculated medium made up of ultrapure water $(1 \mathrm{~L})$, $\mathrm{NH}_{4} \mathrm{Cl}(3 \mathrm{~g}), \mathrm{FeSO}_{4} \cdot 7 \mathrm{H}_{2} \mathrm{O}(0.2 \mathrm{~g}) . \mathrm{MgSO}_{4} \cdot 7 \mathrm{H}_{2} \mathrm{O}(2 \mathrm{~g})$. $\mathrm{KH}_{2} \mathrm{PO}_{4}(2 \mathrm{~g})$ peptone $(2 \mathrm{~g})$, yeast extract (2 g) malt extract $(2 \mathrm{~g})$ and glucose $(20 \mathrm{~g})$ after $48 \mathrm{~h}$ of incubation in the dark at $28^{\circ} \mathrm{C}$ on rotary shaker $(220 \mathrm{rpm}, 3.81 \mathrm{~cm}$ throw), the suspension was macerated and employed as moniliformin [12]. For production of moniliformin 2.5 $\mathrm{ml}$ aliquots were added to $250 \mathrm{ml}$ Erlenmeyer flasks containing $50 \mathrm{ml}$ of production medium consisting of ultrapure water, $\left(\mathrm{NH}_{4}\right)_{2} \mathrm{HPO}_{4}(1 \mathrm{~g}) . \mathrm{KH}_{2} \mathrm{PO}_{4}(3 \mathrm{~g}), \mathrm{MgSO}_{4}$ $7 \mathrm{H}_{2} \mathrm{O}(0.2 \mathrm{~g}) \mathrm{NaCL}(5 \mathrm{~g})$, Sucrose (40 g) and Glycerol $(10 \mathrm{~g})$, final $\mathrm{pH}(6.2)$. The flasks were covered in aluminum foil to protect the toxin from the light and incubated for 10 days [13].

\subsubsection{Monilformin Analysis}

A $500 \mu \mathrm{l}$ aliquots of culture filtrate was loaded onto a waters sep-pak ${ }^{\circledR}$ RP-18column pre-conditioned with water. The column was eluted with $2 \mathrm{ml}$ of ion-pair solution (990:10 mix of 85:15 water/acetonitrile and 100:48:1.1
$\mathrm{MKH}_{2} \mathrm{PO}_{4} / \mathrm{BU}_{4} \mathrm{~N}^{+} \mathrm{OH}$ [14]. A $100 \mu \mathrm{l}$ aliquot was chromatographed on a Lichrosorb ${ }^{\circledR}$ RP-18 250*4.6 MM HPLC with the ion-pair solution described above. The moniliformin was detected with the same detector as above and concentration evaluated by integration at $230 \mathrm{~nm}$. Concentrations were determined by reference to calibration curves established with standard provided by P. Scott of Health Canada [15].

\subsubsection{Fumonisin Analysis}

The cultured were filtered as above and analysis was performed on each replicate flask respectively as follows: A1 $\mathrm{ml}$ aliquot of filtrate was applied to abondElut Certify $\Pi^{\circledR}$ (200 mg, varian) column preconditioned by aspiring methanol $(6 \mathrm{ml})$ and water $(6 \mathrm{ml})$ under vacuum. The minicolumns were then washed with water $(6 \mathrm{ml})$ and methanol $(6 \mathrm{ml})$. Fumonisins were eluted with $0.1 \%$ trifluoroacetic acid (TFA) in methanol $(3 \mathrm{ml})$. Fumonisin was quantified by HPLC as follows [15]. The TFA/ methanol/methanol fraction from the clean-up column was concentrated to dryness and taken up in $1 \mathrm{ml}$ of methanol. A20 $\mu \mathrm{L}$ aliquot was transferred to $2 \mathrm{ml}$ vial and dried under stream of nitrogen. The residue was redissolved in $100 \mu \mathrm{L}$ of $0.05 \mathrm{M}$ sodium borate buffer, $\mathrm{pH}$ 8.3 (adjusted with $1 \mathrm{NHCl}$ ). A freshly prepared solution of 4-fluoro-7-nitrobenzenofurazan (NBD-F) [100 $\mu \mathrm{L}$ of $22 \mathrm{Mm}$ NBD-F (Molecular probes Inc.) in 95\% ethanol] was added. After heating for $70 \mathrm{Secs}$ at $70^{\circ} \mathrm{C}$, the solution was quenched in an ice bath and made up to $500 \mu \mathrm{L}$ with a 1:1 mixture of HPLC mobile phases $\mathrm{A}(0.05 \mathrm{M}$ $\mathrm{NaH}_{2} \mathrm{PO}_{4} /$ Methanol adjusted to $\mathrm{pH} 6.3$ with $2 \mathrm{~N} \mathrm{NaoH}$, 1:1) and $\mathrm{B}$ (acetonitrile/ $\mathrm{H}_{2} \mathrm{O}, 8.2$ ). A $20 \mu \mathrm{L}$ aliquot was injected in duplicate onto aLichrosorb ${ }^{\circledR} 5 \mu \mathrm{m} \mathrm{RP}-18250$ $\mathrm{MM} \times 4.6 \mathrm{MM}$ column on a varian vista ${ }^{\circledR} 5500 \mathrm{HPLC}$ with a varian vista ${ }^{\circledR}$ CDS-401 data system. An $11 \mathrm{~min}$ linear geadient of o to $100 \%$ B followed by a 2 min plateau was run at a flow rate of $1 \mathrm{~mL} / \mathrm{min}$. the derivatized fumonisins were detected by their fluorescence at 490 $\mathrm{nm}$ after excitation at $450 \mathrm{~nm}$ (detector: water ${ }^{\circledR}$ model 420-E) are agent blank produced two main peaks at 6.3 min and $12.3 \mathrm{~min}$. Concentrations were determined by refernce to calibration curves of fumonisin isolated in our laboratory (Miller et al., 1994).

\subsection{HPLC Analysis and Method Development}

The HPLC system consisted of a ternary solvent pump (Gynkotek model 480), auto sampler (Gynkotek Gina 50), decade electrochemical detector with a glassy carbon electrode (Antec) and a diode array detector (Gynkotek340S). Gynko soft software V5.60 was used to control the HPLC system and for data acquisition and analysis. The equipment was supplied by Dionex Softron (Idstein, Germany). Three columns, i.e. Multosphere C18 (3 $\mu \mathrm{m}$; 
125, $4 \mathrm{~mm}$ ID), Phenomenex Synergy MAX-RP C12 80A with TMS end-capping ( $4 \mu \mathrm{m} ; 150,4.6 \mathrm{~mm}$ ID) and Phenomenex Synergi Polar RP (ether linkedphenyl phase with polar end-capping) were tested for the chromatographic separation of the above-mentioned substances. The Multosphere column was purchased from CS, Langer wehe, Germany and Phenomenex, Aschaffenburg, Germany supplied the Phenomenex columns. Peak identity was determined by means of retention time and UV spectra that were recorded for all samples in the range $200-400 \mathrm{~nm}$.

\section{Result and Discussion}

Biochemical tests were carried out for studying the production of toxins by Fusarium pathogens involved in the causation of malformation. Eight fungi viz. F. subglutinans, $F$. solani, F. oxyspoum, F. sterilihyphosum, F. proliferatum, $F$. moniliforme, $F$. avena and $F$. chlamydspore were tested using susceptible Sadekia cultivar as inoculated as apical injection with culture filtrate (Table 1). Data pertaining to artificial inoculations revealed that effort to produce disease by apical injection with culture filtrate. For Fusarium subglutinans proved to be the dominant fungus with $100 \%$ sample's infection. Fungi $F$. oxysporum, $F$. sterilihyphosum and $F$. proliferatum showed moderate infection in induced typical malformation symptoms in inoculated mango seedlings.

Toxin production by Fusarium spp: determination of moniliformin and fumonisin

The ability of different Fusarium isolates to produce moniliformin was determined by grown the strains on liquid culture media (Table 2 and Figure 1). Moniliformin was the secondary metabolite mostly produced by the in vitro cultures of the Fusarium isolates analyzed

Table 1. Comparative virulence of selected Fusarium isolates on inoculated mango cv. Sedekia seedlings.

\begin{tabular}{ccc}
\hline \multirow{2}{*}{ Treatment } & \multicolumn{2}{c}{ Injection buds with culture filtrate } \\
\cline { 2 - 3 } & Disease incidence \% & Disease severity \\
\hline F. subglutinans & 100 & 4.0 \\
F. solani & 0.0 & 0.0 \\
F. oxyspoum & 25.0 & 0.3 \\
F. sterilihyphosum & 25.0 & 2.0 \\
F. proliferatum & 25.0 & 1.3 \\
F.moniliforme & 0.0 & 0.0 \\
F.avena & 0.0 & 0.0 \\
F.chlamydspore & 0.0 & 0.0 \\
LSD & 12.0 & 0.5 \\
\hline
\end{tabular}

Table 2. Moniliform and fumonisin production by Fusarium isolates in liquid media.

\begin{tabular}{ccc}
\hline Isolates & $\begin{array}{c}\text { Concentration of } \\
\text { moniliformin } \mathbf{\mu g} / \mathbf{m l}\end{array}$ & $\begin{array}{c}\text { Concentration of } \\
\text { fumonisin } \boldsymbol{\mu g} / \mathbf{m l}\end{array}$ \\
\hline F. oxysporum & 6.30 & $\mathrm{ND}$ \\
F. proliferatum. & 4.10 & 0.64 \\
F. avenacum & 3.88 & 0.16 \\
F. chlamydospore & 0.60 & $\mathrm{ND}$ \\
F. subglutinans & 8.51 & 0.50 \\
F. sterilihyphosum & 1.10 & $\mathrm{ND}$ \\
F. solani & $\mathrm{ND}$ & 0.10 \\
F. moniliforme & 6.90 & 8.30 \\
\hline
\end{tabular}

$\mathrm{ND}=$ not detected

using HPLC. A evaluated for moniliformin production, seven isolates were toxin producers, the production levels ranging from 0.51 to $8.90 \mu \mathrm{g} / \mathrm{ml}$. There were found differences in moniliformin production among the Fusarium dependent on the species.

The higher levels were produced by $F$. subglutinans $(8.51 \mu \mathrm{g} / \mathrm{ml})$. Moderate concentrations of moniliformin was produced by F.moniliforme $(6.90 \mu \mathrm{g} / \mathrm{ml}), F$. oxysporum $(6.30 \mu \mathrm{g} / \mathrm{ml}), F$. proliferatum $(4.10 \mu \mathrm{g} / \mathrm{ml})$ and F. sterilihyphosum $(1.10 \mu \mathrm{g} / \mathrm{ml})$. The lowest concentration was obtained by $F$. chlamydospore $(0.60 \mu \mathrm{g} / \mathrm{ml})$.

Fumonisin was the secondary metabolite mostly produced by the in vitro cultures of the Fusarium isolates analyzed using HPLC (Table 2 and Figure 2). A evaluated for total fumonisin production (FB1 + FB2), seven isolates were toxin producers, the production levels ranging from 0.10 to $8.30 \mu \mathrm{g} / \mathrm{ml}$. There were found differences in fumonisin production among the Fusarium dependent on the species. The higher levels were produced by $F$. moniliforme $(8.30 \mu \mathrm{g} / \mathrm{ml})$. Moderate concentrations of moniliformin was produced by $F$. proliferatum $(0.64 \mu \mathrm{g} / \mathrm{ml})$ and $F$. subglutinans $(0.50 \mu \mathrm{g} / \mathrm{ml})$, The lowest concentration was obtained by $F$. solani $(0.10$ $\mu \mathrm{g} / \mathrm{ml})$.

$F$. subglutinans and $F$. moniliforme appear to have high level and different toxin profiles. This suggests that thèse fungi can cause malformation, necrosis via the production of phytotoxic metabolites. Some isolates of the species i.e. F. subglutinans, F. sterilihyphosum, $F$. oxysporum and $F$. proliferatum that were highly toxic to mango seedlings and produce moniliformin, suggesting that this toxins can be involved. Fusarium mycotoxins continue to occur in agricultural commodities as a result of fungal contamination hence presenting serious animal and human health problems. Various Fusarium species 
have recently been found to produce several mycotoxins as moniliformin $[9,11]$. Moniliformin is formed in many cereals by a number of Fusarium species that include, besides $F$. moniliforme, $F$. avenaceum. $F$. subglutinans, $F$. proliferatum and others [4]. Malformin-like sub-

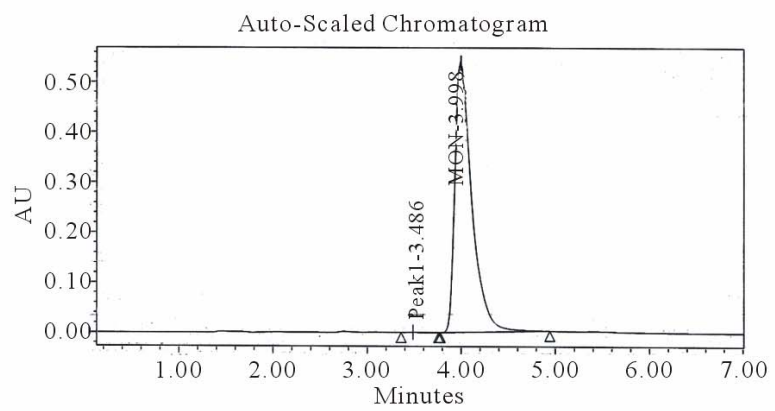

Control
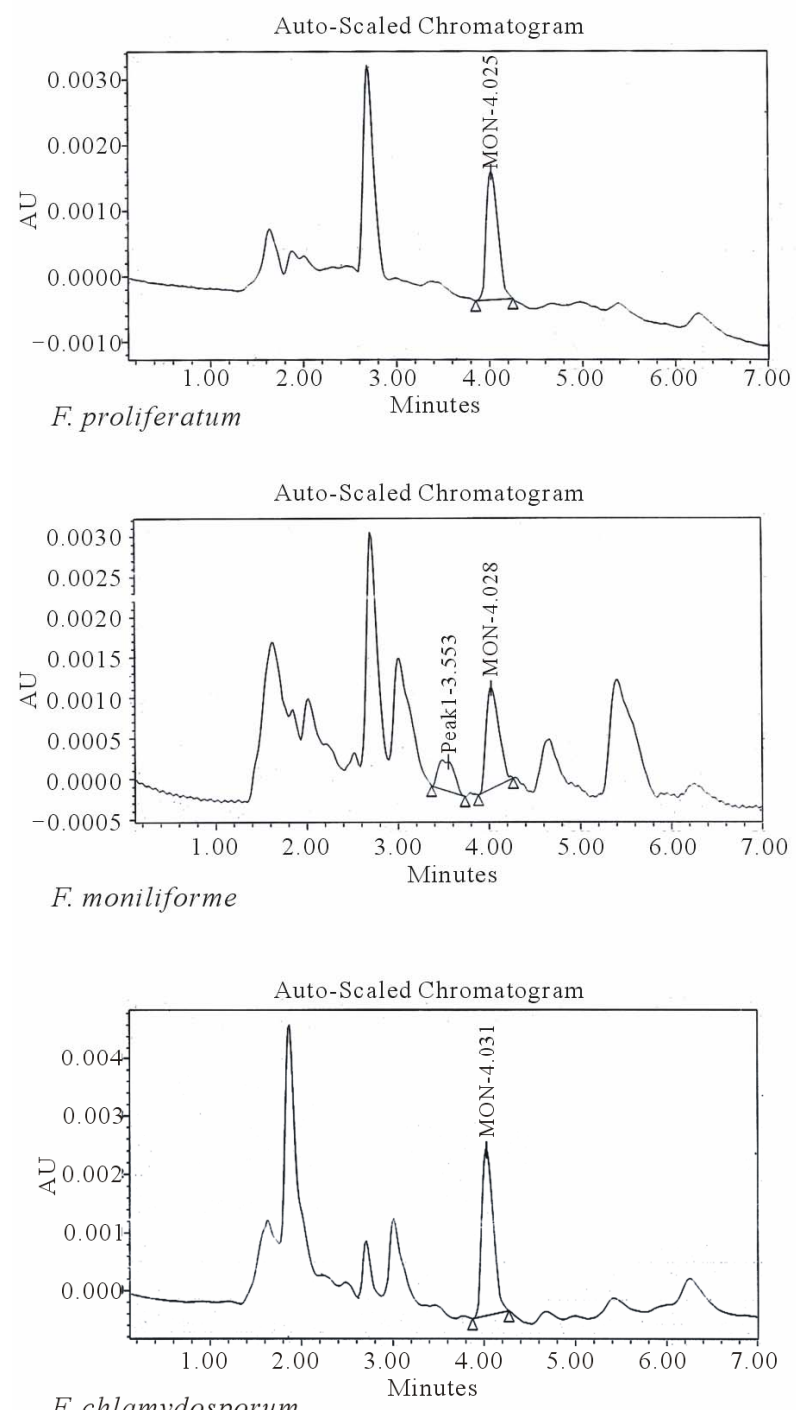

F. chlamydosporum stances are somehow involved in the causation of malformation, with malformin-stimulated ethylene production [10] causing a hormonal imbalance and consequently disturbed metabolism inducing malformation.

Related, recently described species that have been

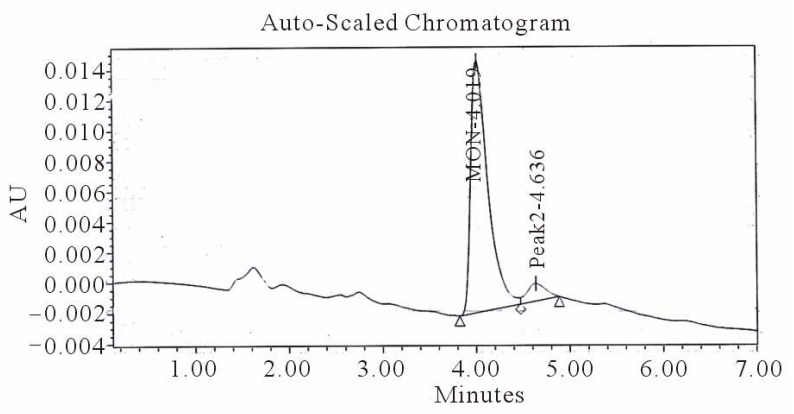

F. oxysporum

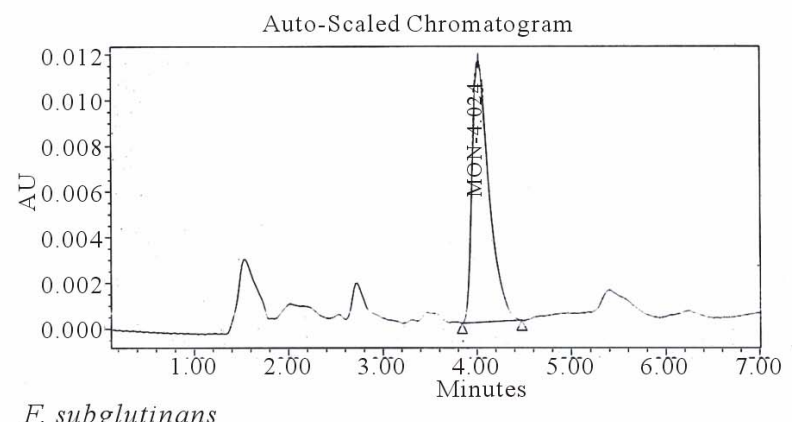

F. subglutinans

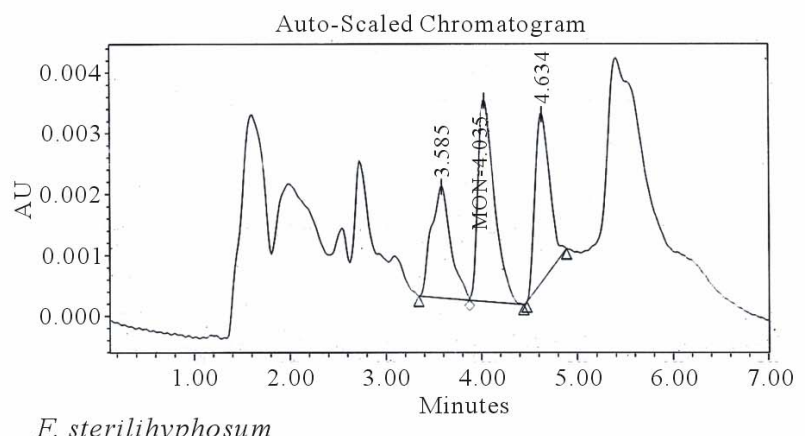

F. sterilihyphosum

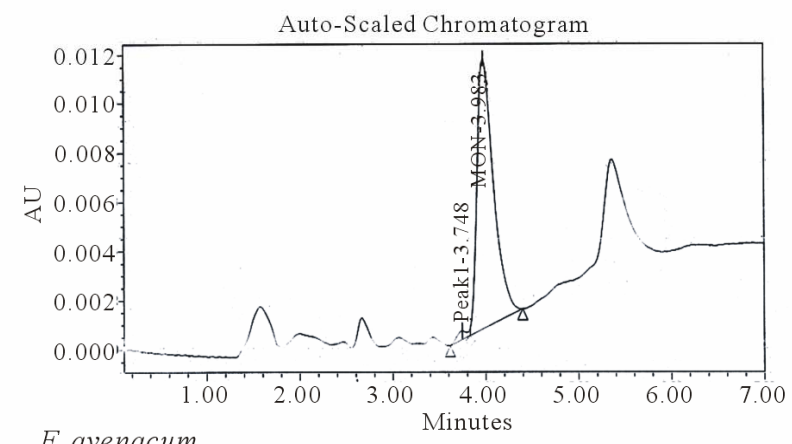

F. avenacum

Figure 1. HPLC of moniliformin production by Fusarium isolates in culture media. 

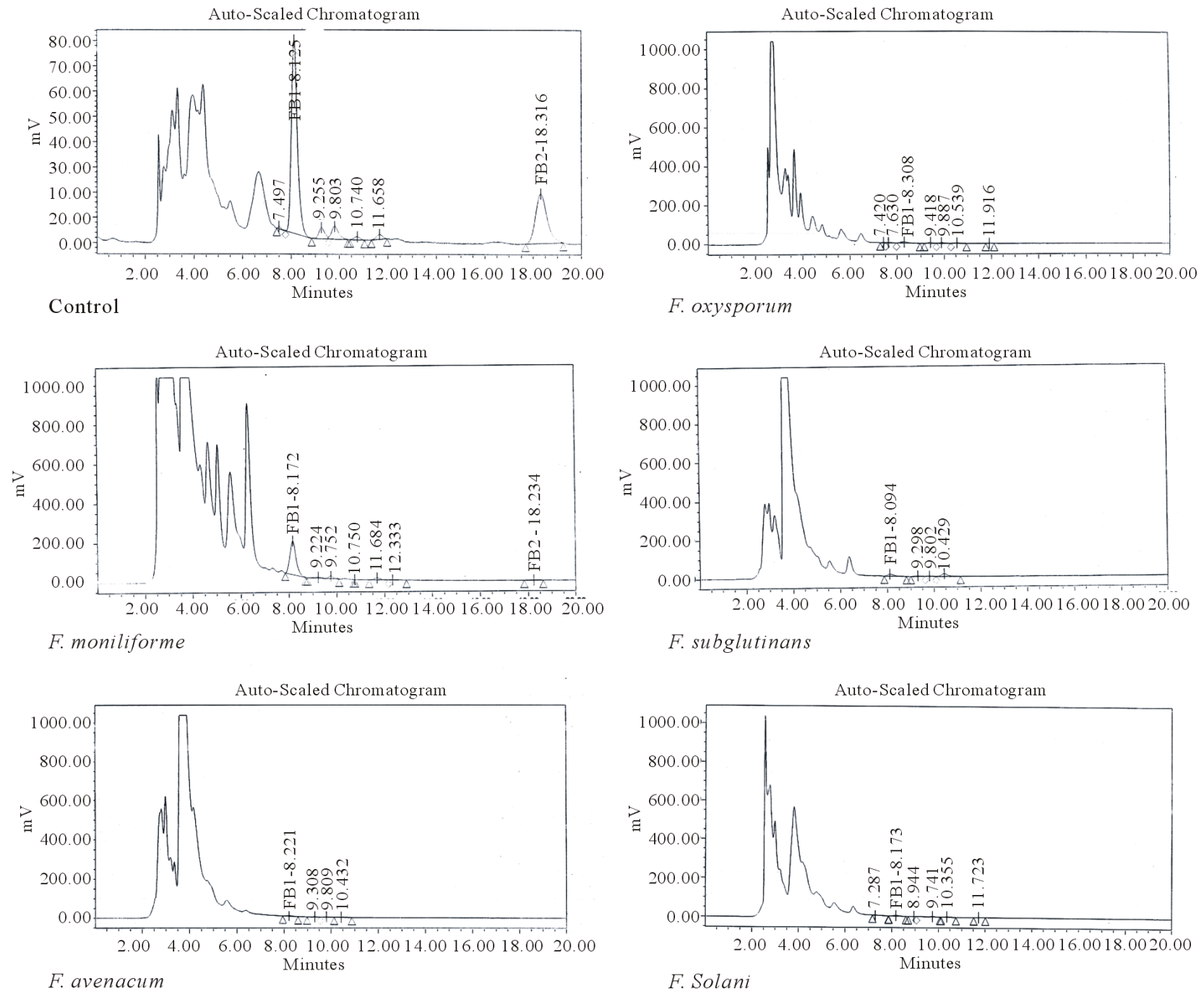

F. avenacum

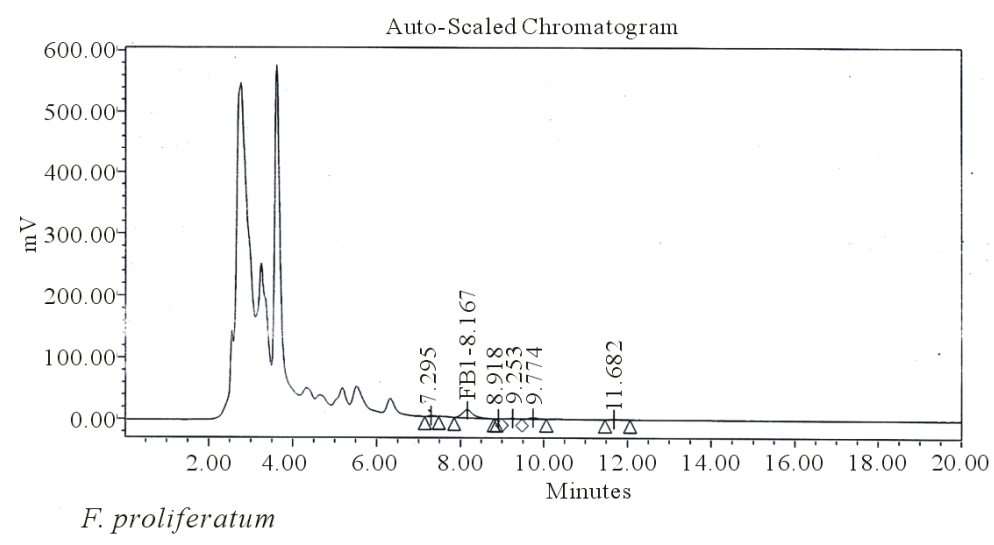

Figure 2. HPLC of fumonisin production by Fusarium isolates in culture media.

shown to produce fumonisins are $F$. dlamini, $F$. napiforme and $F$. nygamai [11]. FB1 concentrations formed by $F$. moniliforme and $F$. proliferatum usually exceed those of FB2. The co-occurrence of these toxins may have synergistic harmful effects on the overall toxicity of the isolates, and may be a greater problem than initially lyte anticipated. Different Fusarium species dominated at different stages of development and a good correlation 
was found between fumonisins and the presence of $F$. moniliforme and $F$. proliferatum. The occurrence of very high levels of fumonisin B\# in some samples was correlated with the presence of strains producing abundant fumonisin B\# in the laboratory [16].

\section{Acknowledgements}

This manuscript funded from the project "New applied approaches to promote productivity and Quality of some fruit crops (Mango)" National Research Centre, 2007 to 2010.

\section{REFERENCES}

[1] R. C. Ploetz, "Malformation: A Unique and Important Disease of Mango, Mangifera Indica L," In: B. A. Summerell, J. F. Leslie, D. Backhouse and W. L. Bryden, Eds., Fusarium: Paul E. Nelson Memorial Symposium, American Phytopathological Society (APS) Press, St Paul, 2001, pp. 233-247.

[2] Z. Singh and B. S. Dhillon, "Comparative Developmental Morphology of Normal and Malformed Floral Organs of Mango (Mangifera IndicaL.)," Trop Agriculture, Trinidad, Vol. 67, 1990, pp. 143-148.

[3] J. Kumar and S. P. S. Beniwal, "A Method of Estimating Cultivar Susceptibility against Mango Malformation," Tropical Pest Management, Vol. 33, 1987, pp. 208-210.

[4] M. I. Khaskheli, M. Pathan, M. Jiskani, M. H. Soomro and G. B. Poussio, "First Record of Fusarium Nivale (FR.) Ces. Associated with Mango Malformation Disease (MMD) in Pakistan," Pakistan Journal of Botany, Vol. 40, No. 6, 2008, pp. 2641-2644.

[5] W. M. Haggag and M. E. A. El-Wahab, "First Report of Fusarium sterilihyphosum and F. Proliferatum-Induced Malformation Disease of Mango in Egypt," Journal of Plant Pathology, Vol. 91, No. 1, 2009, pp. 231-240.

[6] J. Kumar and S. P. S. Beniwal, "Mango Malformation," In: J. Kumar, H. S. Chaube, U. S. Singh, A. N. Mukhopadhyay, Eds., Plant Diseases of International Importance, Prentice Hall, New York, Vol. 3, 1992, pp. 357393.

[7] Z. Singh and B. S. Dhillon, "Presence of Malformin-Like Substance in Malformed Floral Tissues of Mango,"
Journal of Phytopathology, Vol. 125, No. 1, 1989a, pp. 17-123.

[8] S. Ram, "Horticultural Aspects of Mango Malformation," Acta Horticulture, Vol. 291, 1991, pp. 235-252.

[9] Z. Singh and B. S. Dhillon, "Effect of Naphthalene Acetic Acid, Ethrel, Dikegulac and Hand Deblossoming on Floral Malformation, Flowering, Yield and Fruit Quality of Mango (Mangifera Indica L.)," Journal of Phytopathology, Vol. 120, 1986, pp. 245-248. doi:10.1111/j.1439-0434.1987.tb04438.x

[10] Z. Singh and B. S. Dhillon, "Hormonal Changes Associated with Vegetative Malformation of Mango (Mangifera indica L.)," Journal of Phytopathology, Vol. 125, No. 3, 1989b, pp. 193-197. doi:10.1111/j.1439-0434.1989.tb01060.x

[11] P. E. Nelson, R. D. Plattner, D. D. Shackelford and A. E. Desjardins, "Fumonisin B1 Production by Fusarium Species other than F. Moniliforme in Section Liseola and by Some Related Species," Applied and Environmental Microbiology, Vol. 58, No. 3, 1992, pp. 984-989.

[12] J. D. Miller, M. E. Savard, A. Sibilia, S. Rapior, A. D. Hocking and J. I. Pitt, "Production of Fumonisins and Fusarins by Fusarium Moniliforme from Southeast Asia," Mycologia, Vol. 85, No. 3, 1993, pp. 385-391. doi: $10.2307 / 3760700$

[13] M. E. Savard and J. D. Miller, "Characterization of Fusarin F, a New Fusarin from Fusarium Moniliforme," Journal of Natural Products, Vol. 55, No. 1, 1992, pp. 64-70. doi: $10.1021 / \mathrm{np} 50079 \mathrm{a} 010$

[14] P. M. Scott and G. A. Lwrence, "Liquid Chromatographic Determination and Stability of the Fusarium Mycotoxin Moniliformin in Cereal Grains," Journal of the Association of Official Analytical Chemists, Vol. 70, No. 5, 1987, pp. 850-853.

[15] J. D. Miller, "Epidemology of Fusarium Ear Diseases," In: J. D. Miller and H. L. Trenholm, Eds., Mycotoxins in Grain, Eagan Press, St. Paul, 1994, pp. 19-36.

[16] S. N. Chulze, M. L. Ramirez, M. C. Farnochi, M. Pascale, A. Visconti and G. March, "Fusarium and Fumonisins Occurrence in Argentinian Corn at Different Ear Maturity Stages," Journal of Agricultural and Food Chemistry, Vol. 44, No. 9, 1996, pp. 2797-2801. doi:10.1021/jf950381d 